\title{
CHANGES IN EARLY WINTER BIRD POPULATIONS IN WINNIPEG, MANITOBA (1978 - 2017)
}

\section{Rudolf F. Koes}

135 Rossmere Crescent

Winnipeg, MB R2K 0G1

rkoes@mymts.net

\section{Peter Taylor}

P.O. Box 597

Pinawa, MB ROE 1LO

taylorp@granite.mb.ca

Christmas Bird Counts (hereafter CBCs) provide an excellent window on changes in bird populations during early winter. Although the count data are not collected following strict scientific procedures, they do follow certain standardized rules, they are generally conducted by experienced birders, and the results are vetted by the count compilers and can therefore be used to illustrate changes with a certain degree of confidence. In this paper we have analyzed data from 40 years of counts in the city of Winnipeg, focusing on a number of bird species that have either declined or increased markedly (or both) during that period, while possible causes for these changes are also discussed. Species that show large fluctuations from year to year, making long-term trends difficult to detect, such as Snowy Owl (Bubo scandiacus), Black-capped Chickadee (Poecile atricapilla), Red- breasted Nuthatch (Sitta canadensis), Bohemian Waxwing (Bombycilla garrulus) and Common Redpoll (Acanthis flammea), are not discussed.

Additional information on wintering bird species in Manitoba in general, including some mentioned in this article, has been provided previously in 1995 and 2007. 1,2

\section{Methods}

The rather arbitrary time span of 40 years has been chosen for a variety of reasons:
1. Data for counts held before the mid-1970s are often incomplete or counts were not conducted at all.

2. Prior to the mid-1970s the number of participants was small, making results less comparable.

3. CBCs prior to 1978 were held on Boxing Day; from 1979 onward Count Day took place in mid-December (14th to 22nd).

4. Particularly through the efforts of Wayne Neily, compiler from 1981 to 1997, participation increased from the late 1980 s and has since fluctuated between about 70 and 100 field

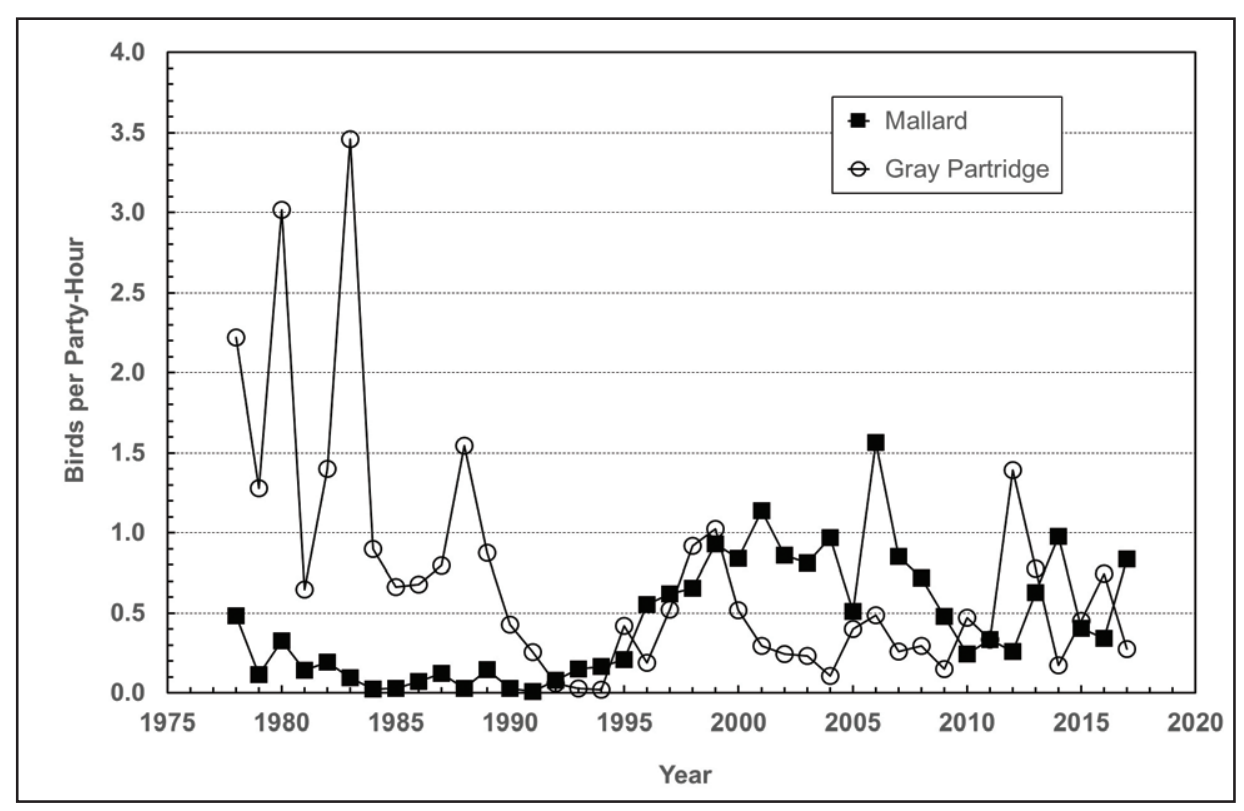

FIGURE 1. Winnipeg CBC data for Mallard and Gray Partridge.

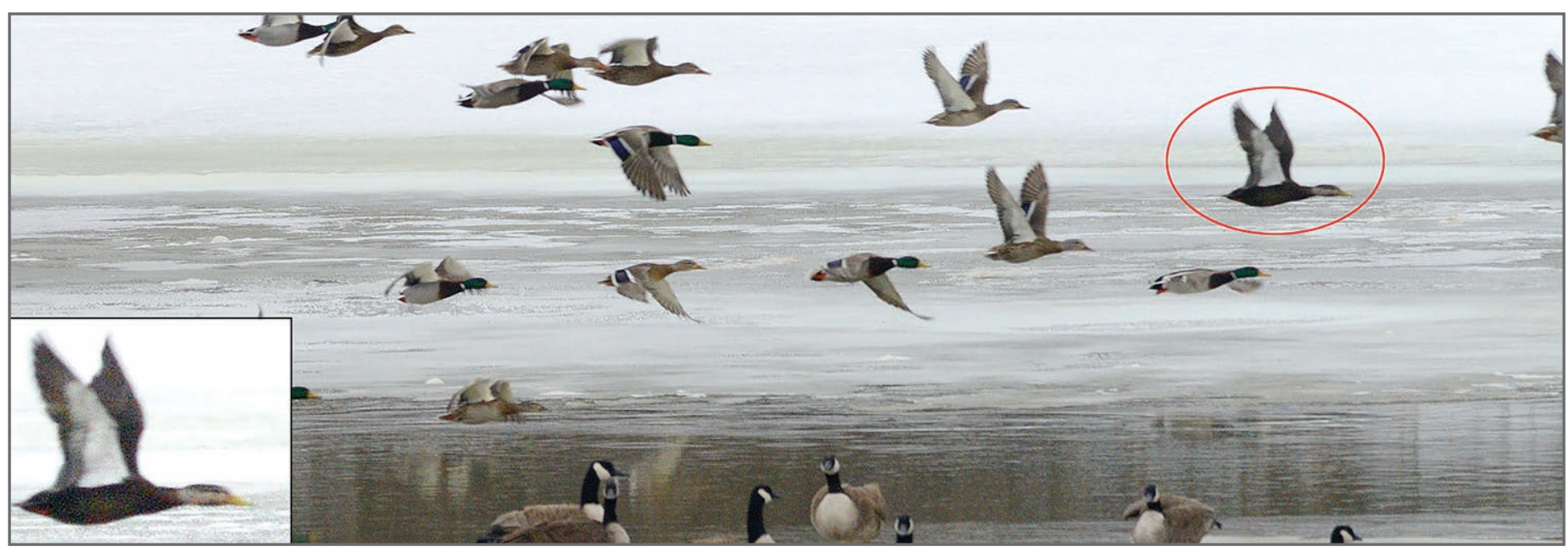

FIGURE 2. Mallards regularly winter at a few locations in Winnipeg. They are attracted to small patches of open water, often at sewage treatment plant outlets, or where locals feed the birds. Occasionally an American Black Duck will remain with them, such as here on February 20, 2017. Photo credit: Garry Budyk. 
observers, with smaller numbers of feeder watchers.

All counts from 1978 to 2017 have been included in this analysis. All the data have been obtained from the National Audubon Society's website and from personal notes (RFK). Eighteen species in total are discussed here, in check-list order. Actual maximum numbers of birds observed are included for each species, but the discussion is based primarily on count rates, i.e., birds per party-hour (b/p-h). While the limitations of this correction for effort are recognized, especially for locally concentrated species such as waterfowl, it is the most commonly used approach to comparison of CBC data. ${ }^{3}$ Weather data were not considered in our analysis.

\section{Species}

\section{Mallard (Anas platyrhynchos)}

Mallards were present in winter in very low numbers until the mid 1990s. From then on numbers increased dramatically, with a peak count of 341 in 2006, but there has been an overall decline since about 2010 (Figure 1). Most birds have been found on open water at the West End Water Pollution Control Centre, more commonly known as the Wilkes Sewage Ponds or Lagoons. From

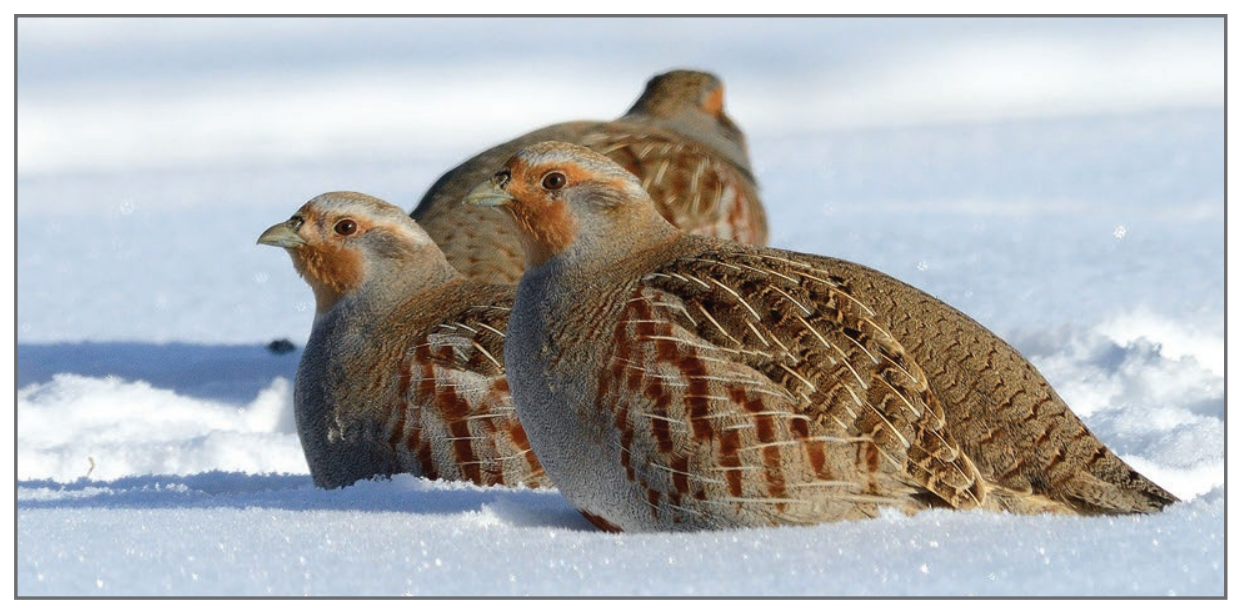

FIGURE 3. Although Gray Partridge numbers have declined in Winnipeg, they are still relatively easy to find in winter at the outskirts of the city, such as here on December 18, 2017. Photo credit: Garry Budyk. there flocks fly to stretches of open water along the Assiniboine River and to FortWhyte Alive, a nature centre with an aerated pond. Changes to outflow patterns into Winnipeg's rivers from the city's three treatment centres in the last decade have led to a reduction of open water available to the birds, which is likely responsible for the noted recent decrease. This is offset by local feeding, such as at FortWhyte Alive, at the confluence of Sturgeon Creek and the Assiniboine River, and at the outlet of the North End Pollution Control Centre into the Red River. At times this species associates with small numbers of other waterfowl, such as Canada Goose or American Black Duck (Figure 2).

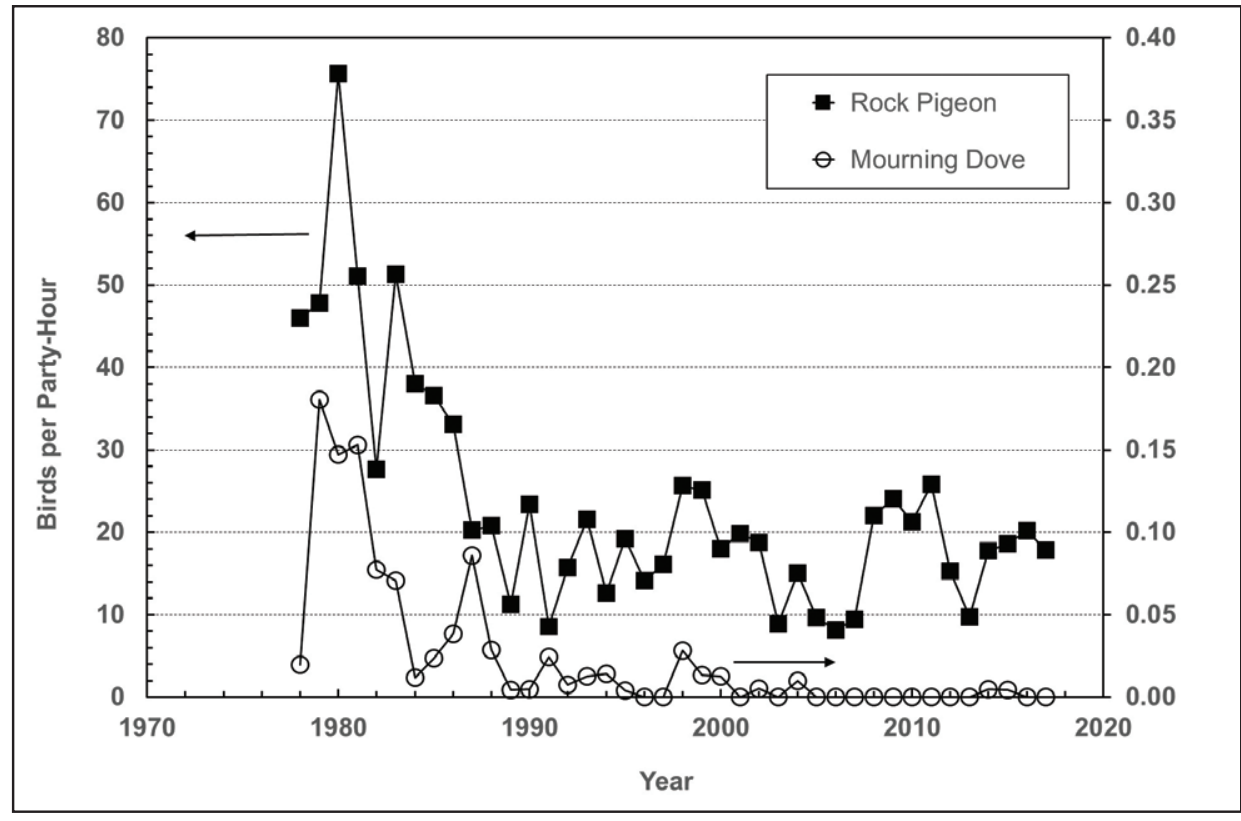

FIGURE 4. Winnipeg CBC data for Rock Pigeon and Mourning Dove.

\section{Gray Partridge (Perdix perdix)}

Peak numbers of Gray Partridges (Figure 3) were noted at Winnipeg until the mid-1980s, with tallies as high as $3.5 \mathrm{~b} / \mathrm{p}-\mathrm{h}$ (maximum 595 birds in 1983). Since that time no counts have exceeded $1.5 \mathrm{~b} / \mathrm{p}$-h (Figure 1). Interpreting decreasing numbers of Gray Partridges is difficult, as the species' populations are known to fluctuate tremendously. Factors impacting this species include cool, wet summers, severe winters, and probably predation by Red Foxes (Vulpes fulva). ${ }^{4}$ However, in Winnipeg undoubtedly the main cause is loss of habitat, due to conversion of farmland at the city's periphery to residential neighbourhoods. The species has barely maintained a toe-hold in the eastern part of Winnipeg, where it was formerly common, and even in the Rosser area of northwest Winnipeg, its former stronghold, numbers have plummeted. With continued loss of habitat, this trend is expected to continue.

\section{Rock Pigeon (Columba livia)}

From a peak of 9,250 (75.6 b/p-h) pigeons in 1980 (the highest tally in all of North America that year), the totals steadily decreased during the next decade and have fluctuated between 8 and 26 b/p-h (1,766 to 6,796 birds tallied) since 1987 (Figure 4). These declines can be attributed to a number of factors, foremost of which would be the introduction of covered, cylindrical 
hopper railcars for grain, commencing in 1972. ${ }^{5}$ These cars greatly reduced the amount of spilled grain at railway yards, thereby limiting the food available to Rock Pigeons. In addition, changes in bridge and building construction have reduced the availability of nesting and roosting places. It is also likely that reduced observer coverage of innercity areas during the count has made a small contribution to the decrease in tallied birds.

\section{Mourning Dove (Zenaida macroura)}

Mourning Doves were a regular feature of Winnipeg counts during the 1970s and 1980s, with totals frequently in the high teens or low twenties (maximum, 25 in 1981). Since 1989 no count has exceeded single digits and since 2000 the species has been reported only on six occasions (Figure 4). During those earlier years, some feeding stations hosted birds year after year. These stations were located in well-wooded suburban areas or at farm yards; many long-time observers will remember the doves at feeders on Victoria Crescent and at Slater Avenue.

It appears that the decrease in wintering birds has coincided with an overall decrease of the breeding population in Winnipeg and southeastern Manitoba as a whole. This decrease was hinted at in The Birds of Manitoba in 2003, which stated that Breeding Bird Survey (BBS) results noted an increase between 1967 and 1982, then a gradual decline to 1967 levels by the late 1990s. ${ }^{6}$ Although the species has increased in many other jurisdictions in Canada, especially in Québec and the Atlantic provinces, Manitoba and British Columbia are exceptions; provincially the loss has been nearly 40\% since 1970. ${ }^{7}$ The Mourning Dove is now a rare breeder within the city (RFK, pers. ob.). Though not hunted in Manitoba, the Mourning Dove is the leading game-bird in North

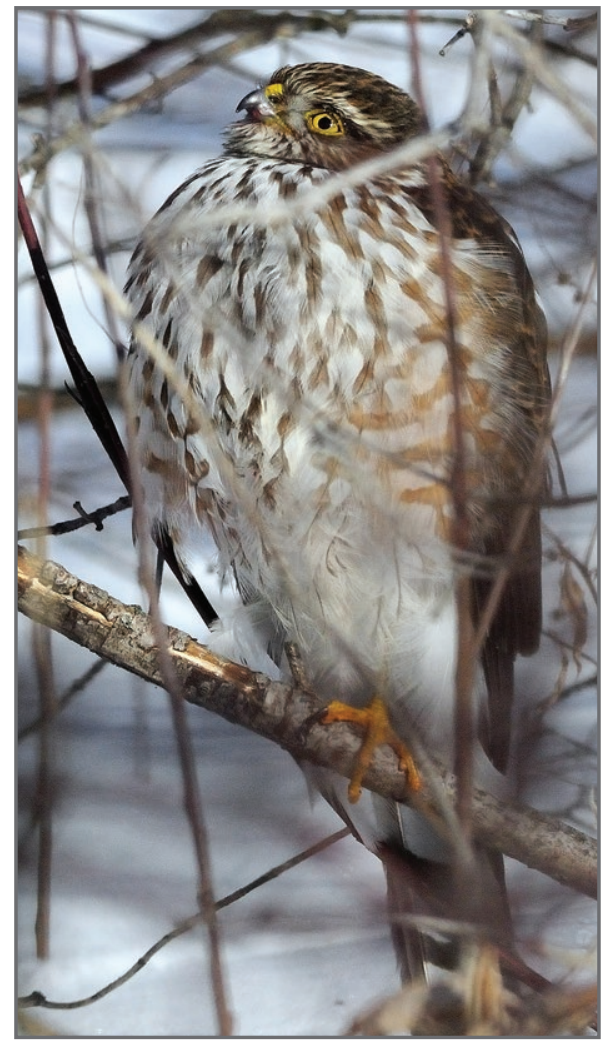

FIGURE 5. Sharp-shinned Hawks have become regular winterers in small numbers in Winnipeg in recent years. This bird was photographed on February 20, 2016. Photo credit: Garry Budyk.

America, with an annual harvest of more than 20 million birds by one million hunters, ${ }^{8}$ but the continentwide trend is only slightly decreasing. Suggested reasons for the observed decline in Manitoba include intensified agriculture, a large-scale shift from grain to pulse production, and possibly also lead-shot ingestion. ${ }^{9}$

\section{Sharp-shinned Hawk (Accipiter striatus)}

Small numbers of Sharp-shinned Hawks have been found wintering in Manitoba intermittently since the winter of 1989-1990 (Figure 5). ${ }^{10}$ In 2005 one was recorded for the first time on the Winnipeg $C B C$ and singles have been seen on six counts since, while in 2017 three birds were tallied. As was the case for Bald Eagle, the traditional winter range of Sharp-shinned Hawk extended to the states near Manitoba; with somewhat warmer winters in recent decades a slight northward shift was not unexpected. Cooper's Hawks (Accipiter cooperii) have been reported occasionally as well, but upon investigation most of these birds turned out to be misidentified Sharpshinned Hawks.

\section{Bald Eagle (Haliaeetus leucocephalus)}

The success of the Bald Eagle as an increasing breeder in Manitoba has previously been reported in Blue Jay. ${ }^{11}$ Concomitant with this increase in breeders has been an increase in wintering birds in the southern regions of the province. First reported on the Winnipeg CBC in 2001, the species has been seen every year since, with a peak reported count of nine in 2017. Actual numbers are difficult to ascertain, as individual birds range widely during the day and there are doubtless some repeat sightings. An attempt has been made to compensate for this by asking observers to indicate the location, time and, if applicable, direction of flight of the birds, and the counts were adjusted accordingly when reporting to the National Audubon Society.

Factors causing the increased counts appear to include the general increase in the breeding population, with a few pairs now nesting within city limits, an adequate supply of food in the form of carrion and (especially in early winter) crippled waterfowl, and the subtle effects of global warming. Outside the city limits, Bald Eagles winter in increasing numbers as well, especially in relatively mild winters. Here they are often attracted by offal from poultry farms or hog operations, as well as other edible waste, roadkill, and any open water.

\section{Pileated Woodpecker (Dryocopus pileatus)}

One Pileated Woodpecker was reported on the 1947 Winnipeg CBC. The next one was not until 1999. Since that year the species has been seen annually and it has become a 
regular winter bird in the city, where small numbers have even bred in recent years. There is little doubt that the maturation of trees, especially along rivers and at parks and golfcourses, has been largely responsible for this increase. Such an increase has also been noted elsewhere south of Manitoba's boreal forest, especially in riparian woodland. The largest Winnipeg CBC tally was nine in 2017.

\section{American Kestrel (Falco sparverius)}

American Kestrels were quite rare to absent in Winnipeg in winter until the mid-1970s, then increased albeit with fluctuations until 1991, after which a steady decline took place (Figure 6). This decline coincided with a general downward trend of the North American population documented by BBS results. Between 1966 and 2010 there has been a 47 per cent drop in numbers continent-wide and a map from 2012 shows widespread declines throughout southern Manitoba. ${ }^{12,13}$ Fall tallies, during annual, informal September hawk migration counts in southern Manitoba, have seen similar reduced numbers (pers. ob.). Results for these fall raptor counts have been published annually in the Manitoba Naturalists Society's Bulletin and its successor, Nature Manitoba's News.

The fact that Merlins (Falco columbarius) showed general increasing numbers as wintering birds around the same time as kestrel numbers started to drop may be coincidental, but could point to competition for food (presumably local concentrations of small birds and rodents). The peak kestrel count for the Winnipeg CBC was nine, obtained in both 1989 and 1990.

\section{Merlin (Falco columbarius)}

First recorded on the Winnipeg CBC in 1976, Merlins have been seen annually since, with the exception of 1981. From 1986 there was a marked increase which lasted until 2003, with a record count of 17 birds in
2001 (Figure 6). Tallies have not been adjusted for possible multiple sightings, as this has proven to be more difficult to ascertain than for Bald Eagle. Since 2003 numbers have fluctuated, but there appears to be a declining trend.

The subspecies involved has invariably been Richardson's or Prairie Merlin (F. C. richardsonii) which has experienced a population boom in much of the southern Prairie Provinces in recent decades. ${ }^{14}$ Houston attributes the increase at least in part to the increasing availability of disused crow nests (especially in dense, mature conifers). ${ }^{15}$ Taiga Merlin ( $F$. c. columbarius) has shown similar increases, but it does not have the same northerly wintering tendency.

The apparent decline may be linked to the fact that both European Starling (Sturnus vulgaris) and House Sparrow (Passer domesticus), key prey species in winter, have declined dramatically in recent decades (see European Starling and House Sparrow accounts). There is no correlation between high counts for Merlin and for Bohemian Waxwing, another prey species. West Nile virus killed many nestling Merlins in Winnipeg in 2018 (C. Artuso, pers. comm.), and just one Merlin was recorded in the 2018 CBC.

\section{Black-billed Magpie (Pica hudsonia)}

Black-billed Magpies saw a steady increase in numbers between 1978 and 2002, with a tally of 238 birds in the latter year (Figure 7). This was followed by a calamitous crash, to a low point in 2008, when only 21 birds were counted. The sharp decline commenced in 2003, the year after West Nile virus was first detected in the province. ${ }^{16}$ Corvid species were severely affected by the virus, and it appears that the magpie suffered most losses. Black-billed Magpies have never taken to breeding or wintering in Winnipeg's urban areas, unlike the situation in several cities in the western prairies, notably Saskatoon, Saskatchewan and Edmonton, Alberta. ${ }^{15}$ They have remained confined to the semi-rural outskirts, which are currently being converted on a large scale into residential areas, so it is unlikely that the species will rebound to levels seen early in the 21 st century.

\section{American Crow (Corvus brachyrhynchos)}

American Crows increased in numbers on the Canadian Prairies after the suppression of prairie fires

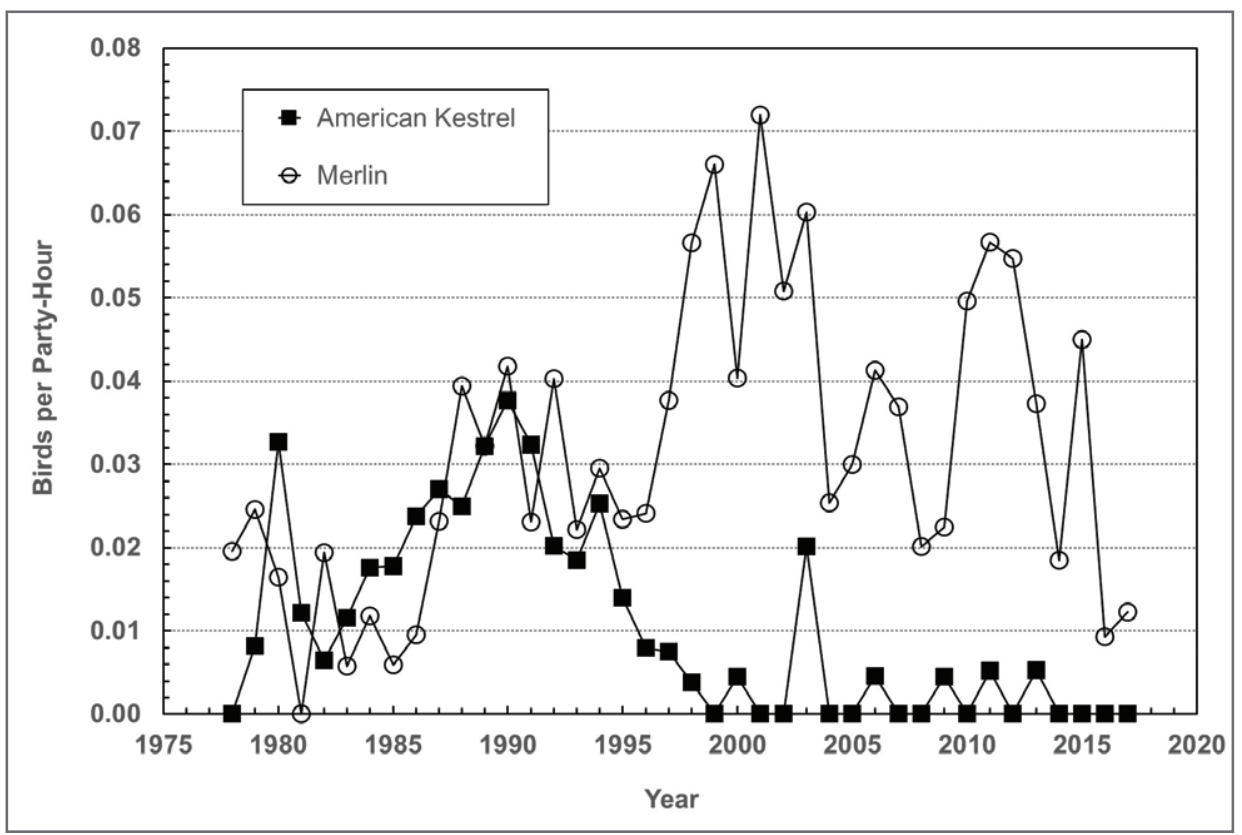

FIGURE 6. Winnipeg CBC data for American Kestrel and Merlin. 


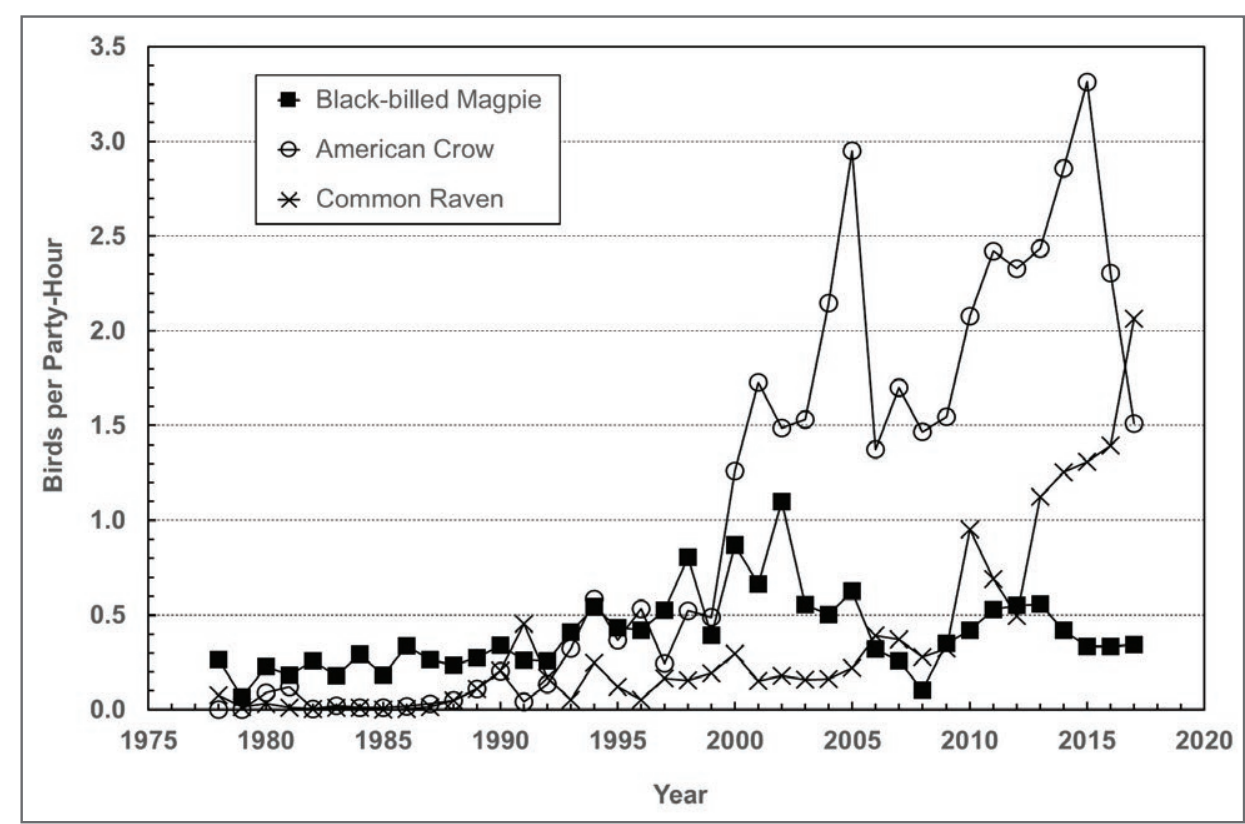

FIGURE 7. Winnipeg CBC data for Black-billed Magpie, American Crow, and Common Raven.

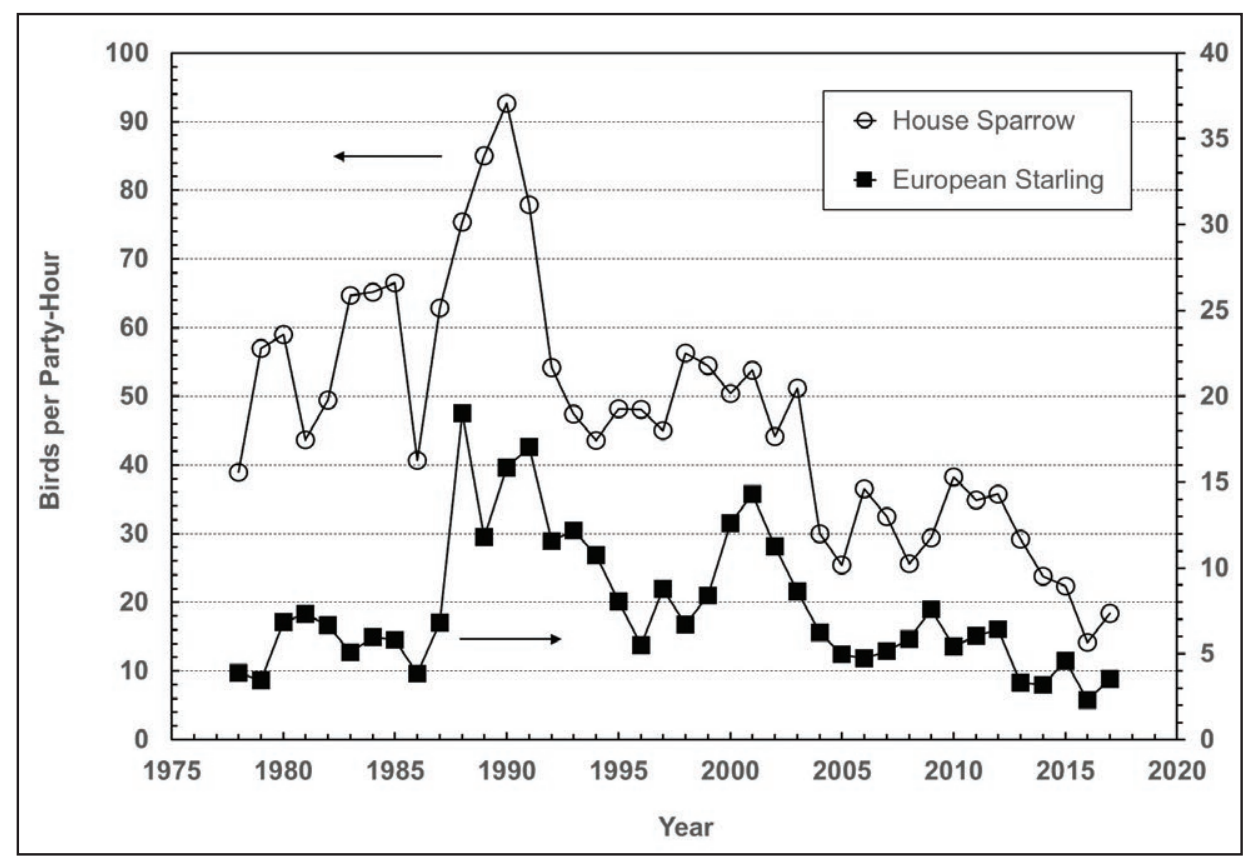

FIGURE 8. Winnipeg CBC data for European Starling and House Sparrow.

in the late 1800s allowed more tree growth, while nesting in cities was rare until the 1960s. ${ }^{15}$ They were considered rare winter birds in Manitoba until the 1990s, when records became more frequent. From 2000 there was a rapid increase to a peak of 590 (2.95 b/ph) in 2005 , followed by a sharp drop in 2006 (Figure 7). After a few years of rather steady numbers, the winter population started to grow again and is currently near its former peak, with a record count of 736 (3.32 b/p-h) in
2015. The drop in 2006 may have been the result of West Nile virus, which was first reported in Manitoba in the summer of 2002 and is known to affect corvids in particular. ${ }^{16}$

There are probably multiple reasons for these high counts in Winnipeg.

1. Maturation of trees, especially conifers, in the city has allowed crows to find plenty of nesting and winter roosting locations, leading to an increase in the number of breeders.

2. Winter temperatures in Winnipeg have consistently been higher than they were a few decades ago.

3. Due to the proliferation of fast food outlets, there is more discarded food available. More American Crows now also winter in small towns and rural areas across southern Manitoba, pointing to climate change as likely being the prime factor involved in the upswing in numbers.

\section{Common Raven (Corvus corax)}

Ravens started to winter in some central Saskatchewan towns in the 1950 s, ${ }^{15}$ foreshadowing their recolonization of the Canadian prairies. They were rare or uncommon winter residents in Winnipeg until more recently. BBS data show an increasing trend on prairie and parkland routes since about $1985 .{ }^{17}$ Not long afterwards, Common Raven tallies on the Winnipeg CBC started to rise, culminating in triple-digit totals since 2010 (Figure 7), and a maximum to date of 504 (2.07 b/p-h) in 2017. Members of the general public, as well as birders, have commented on seeing large flocks of ravens cavorting around tall downtown buildings in recent winters. ${ }^{18}$ Concurrently, hundreds of ravens have in the last few years started to roost at a local hospital, the Health Sciences Centre. ${ }^{19}$ In the past ravens have also roosted in the rafters of the former Winnipeg Stadium (PT, pers. ob.).

Prior to the recent spike in roosting birds in Winnipeg, many ravens commuted between Birds Hill Provincial Park and feeding areas around the city. The reasons for this sudden spike in birds using the Health Sciences Centre for roosting are unclear, but there is little doubt that the local environment is several degrees warmer than outside of the city boundaries and the location is undoubtedly predator-free. Sizeable flights of birds have been seen commuting between the roost site and areas outside of the city, which include the Brady Road garbage dump and areas to the east (PT, pers. ob.). 


\section{European Starling (Sturnus vulgaris)}

The European Starling is a species introduced from Europe that was first recorded in Manitoba in 1925 and its first sighting on the Winnipeg CBC was exactly ten years later, in 1935, when six birds were seen. ${ }^{20}$ Count day tallies barely reached four-digit numbers until 1988, when the count jumped to 5317 birds, or over $19 \mathrm{~b} / \mathrm{p}$-h (Figure 8). Totals remained fairly high for the next few years, but then started to slide, especially from 2001 to $2005 .{ }^{20}$ Count rates in recent years (since 2013) have been less than $5 \mathrm{~b} / \mathrm{p}-\mathrm{h}$. Interestingly, between 2001 and 2005 CBC tallies in rural counts started a gradual climb and with some fluctuations have remained fairly level since. ${ }^{20}$ Most nearby jurisdictions have experienced declining trends, as documented by BBS results. ${ }^{20}$

It should be kept in mind that Winnipeg totals from the late 1980s to the early 1990s were somewhat skewed due to greater-than-usual coverage in the inner city. Indeed, the count of 5,317 in 1988 was accomplished by the largest-ever number of field observers, 100.

Causes for the drop in numbers are difficult to pinpoint. The construction of new bridges, such as the rebuilt Disraeli Freeway bridge over the Red River, has certainly deprived starlings of roosting locations. At this bridge alone a thousand or more birds would roost in winter during the late 1980s and early 1990s. Towards evening, as the starlings came in to roost, one or two Merlins would usually be on hand to partake of the riches (RFK, pers. ob.). Residential home construction has also changed, providing fewer nesting spots.

\section{House Sparrow (Passer domesticus)}

Although the House Sparrow is still an abundant bird (whether native or introduced) on several continents, substantial declines have been noted in North America and Europe in recent decades. There was an estimated drop

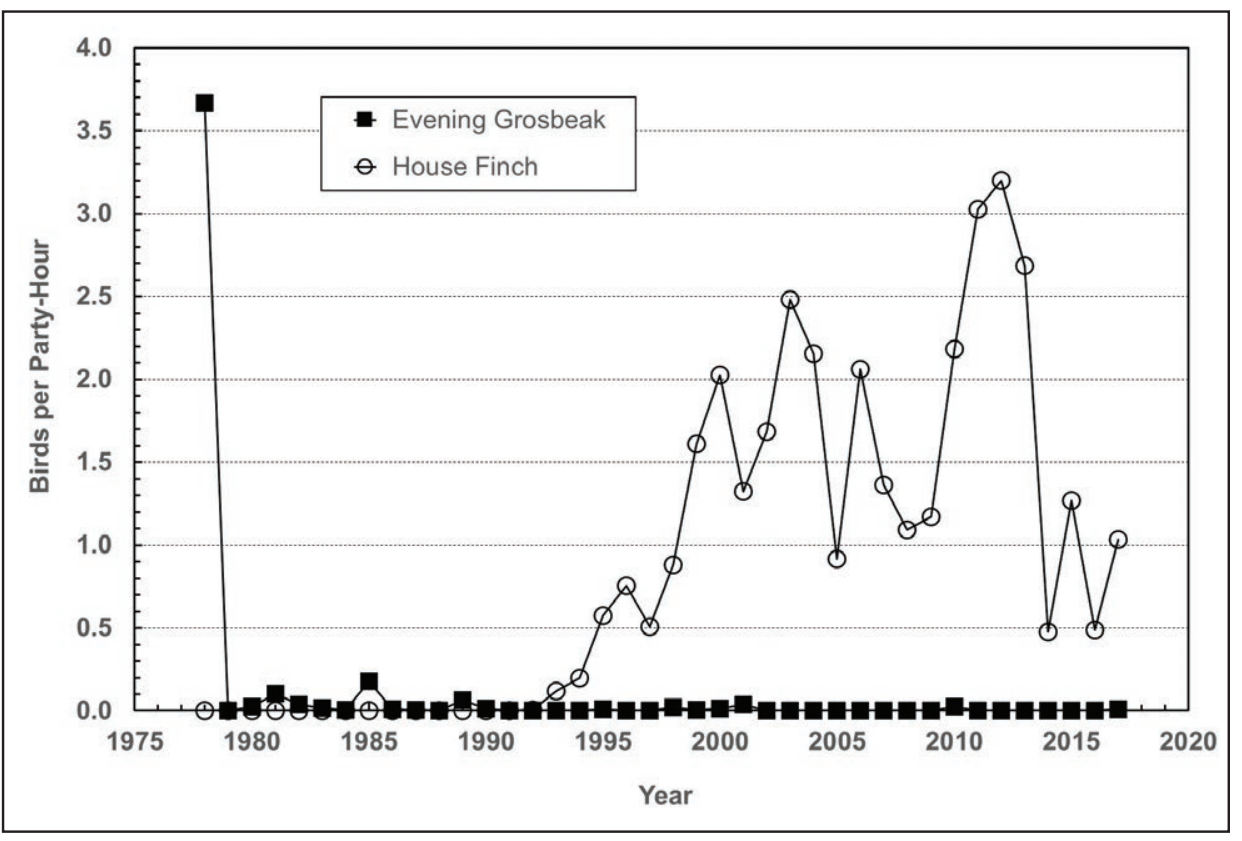

FIGURE 9. Winnipeg CBC data for Evening Grosbeak and House Finch.

of 71 per cent in the United Kingdom between 1977 and 200821, while in the Canadian Maritimes the decline may have been as high as 90 per cent since 1970.22

Causes for the declines are largely undetermined, although lack of invertebrate prey led to starvation of chicks - and therefore lower breeding success - in the United Kingdom, but food availability is probably not the main cause of the declines. ${ }^{23}$ Changes in agricultural practices may have depressed numbers in rural areas, but they have no effect on urban or suburban populations. There is some evidence that House Sparrow numbers decrease as House Finch (Haemorhous mexicanus) numbers increase (see House Finch account). ${ }^{24}$

These declines are well-illustrated by the Winnipeg $C B C$ results (Figure 8 ). The count rate peaked at $92.6 \mathrm{~b} / \mathrm{p}-\mathrm{h}$ in 1990, then saw a sharp drop over four years, followed by a levelling-off during the next decade, and a further drop after 2003. In the past five years counts have not exceeded $30 \mathrm{~b} / \mathrm{p}$-h. The tally of 23,761 birds in 1989 was the highest on the continent, but totals at that time were somewhat skewed by increased coverage of the city's urban core by a dedicated crew of birders. Winnipeg CBCs account for the top 16 all-time highest counts in Canada (Kathy Dale, pers. comm.).

\section{Evening Grosbeak (Coccothraustes vespertinus)}

Evening Grosbeaks have been absent, or present in very low numbers, after the 1960s and 1970s when they were a regular feature of the Winnipeg CBCs. Peak counts were 519 in 1976 and 373 in 1978, while the highest tally since then was 30 in 1985 (Figure 9). After 2002, the species has been recorded only twice.

Elsewhere in their winter range declines have also been noted, although these declines commenced more recently. For example, at the Pinawa-Lac du Bonnet CBC (located at the edge of the boreal forest) count numbers peaked in the 1990s, with a maximum tally of 1663 (29.7 b/p-h) in 1995. They have dropped since, with a recent low count of 133 birds (2.3 b/p-h) in 2017.

These declining winter numbers appear to be part of a general, continent-wide decline, estimated at 50 per cent between 1988 and 2006; causes are unclear and warrant further study. ${ }^{25}$ Prompted by this decline, the Committee on the Status 


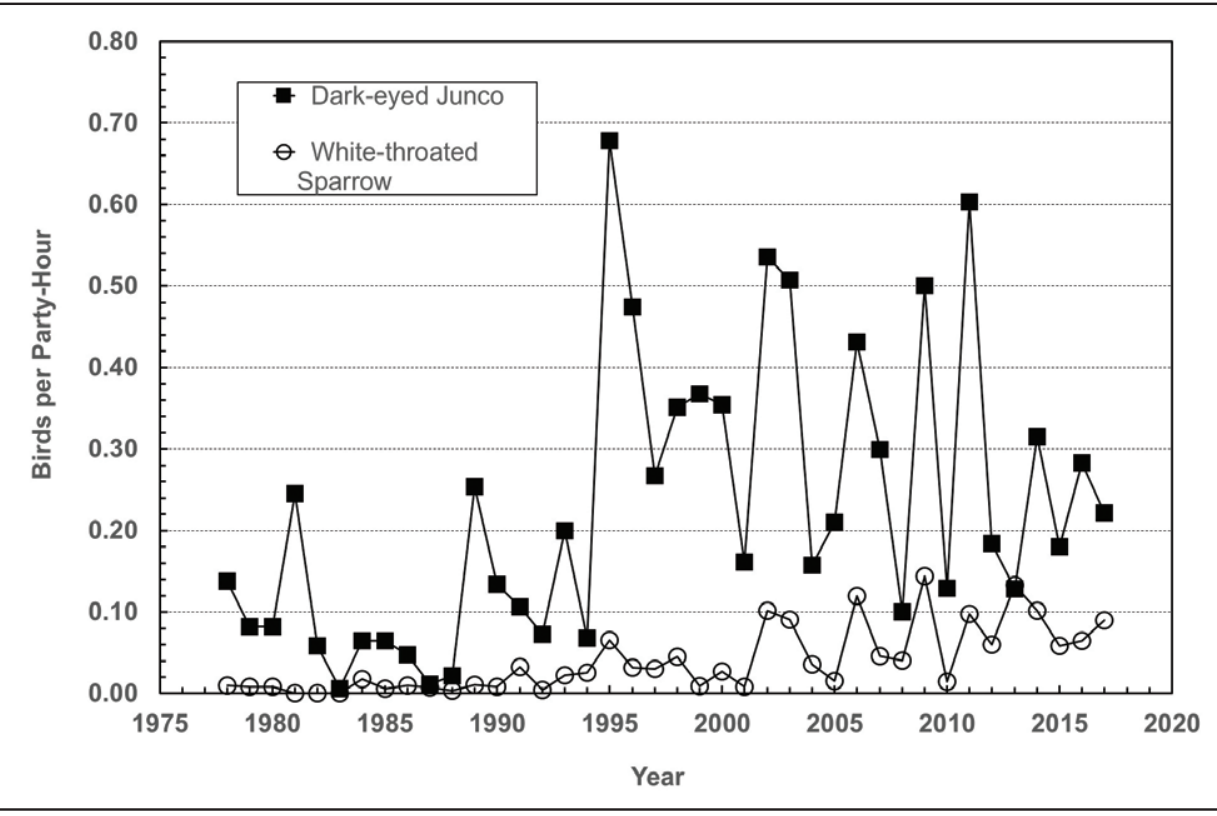

FIGURE 10. Winnipeg CBC data for White-throated Sparrow and Dark-eyed Junco.

of Endangered Wildlife in Canada assessed the Evening Grosbeak's status and determined it to be a Species of Special Concern. ${ }^{26}$

\section{House Finch (Haemorhous mexicanus)}

This finch's cheery song through much of the late winter and early spring is a pleasant addition to the limited bird chorus heard at that time of year. After Manitoba's first House Finch was recorded in 1983, it took 10 years for the species to show up on the Winnipeg CBC. ${ }^{27}$ From that single bird in 1992, tallies grew to 452 in a matter of nine years and a peak of 643 in 2012, after which a rather sharp decline took place (Figure 9). It is too soon to speculate whether this decrease will be permanent, but numbers seem to have stabilized since 2014. Recent research has shown that finch eye disease, which may proliferate at busy feeders, can impact local populations; ${ }^{28}$ nevertheless, the House Finch is probably feeder-dependent during winter in Manitoba.

During the winter season House Finches tend to form sizeable flocks, sometimes containing several dozen birds, while they may vacate many of their regular summer haunts. Knowing the locations of these flocks is critical in obtaining a representative CBC total.

\section{White-throated Sparrow (Zonotrichia albicollis)}

From the mid-1990s on, Whitethroated Sparrows started wintering in increasing numbers in Winnipeg (Figure 10). Whereas they had been found only in low single digits up to then, the totals frequently reached double digits from 1995 on, peaking at 32 in 2009. The upward trend has by no means been steady, with peaks generally occurring every two to three years, followed by markedly lower tallies. Total counts are usually boosted by concentrations of birds at certain feeding stations, particularly in seemingly isolated urban locations, where they associate with House Sparrows (Figure 11). Why these birds end up in downtown spots almost devoid of vegetation is unclear, but they likely become trapped there during inclement weather on their fall migration. The widespread availability of feeding stations has certainly allowed this species to winter successfully in the city, as well as smaller communities across southern Manitoba, a trend that is likely to continue.
Dark-eyed Junco (Junco hyemalis)

Like the previous species, the Dark-eyed Junco is a regular feature of Winnipeg CBCs, and has similarly profited from the popularity of bird feeders. Much more common in winter than the White-throated Sparrow, its highest counts have occasionally exceeded 100 birds, with a maximum of 146 in 1995 (Figure 10). Most Winnipeg birds belong to the Slate-colored race (J. h. hyemalis), but Oregon Junco (J. h. oreganus) is reported with some frequency and there are two records of Gray-headed Junco (J. h. caniceps). ${ }^{1}$ It is likely, however, that most reports of Oregon Junco in Manitoba are in fact referable to the poorly known Cassiar Junco (J. h. cismontanus; C. Artuso, pers. comm.). ${ }^{29}$ There have been no verified CBC records of either Pink-sided Junco (J. h. mearnsi) or White-winged Junco (J. h. aikeni). Most winter juncos are found at suburban feeders, sometimes in small flocks. Unlike White-throated Sparrows, they are rarely found at the urban locations mentioned for that species.

\section{Acknowledgements}

Thanks are due to Kathy Dale of the National Audubon Society, who supplied data on House Sparrow numbers on CBCs in the United States and Canada. Garry Budyk has kindly allowed us to use his fine photographs. Christian Artuso provided many helpful comments on the original manuscript.

All of the internet addresses cited below were accessed on January 25 , 2019.

1. Taylor P, Koes RF. 1995. Rare and marginal winter passerine birds in Manitoba. Blue Jay 53(3):148-158.

2. Taylor P, Koes RF. 2007. Rare and marginal winter non-passerine birds in Manitoba. Blue Jay 65(4):179-200. 


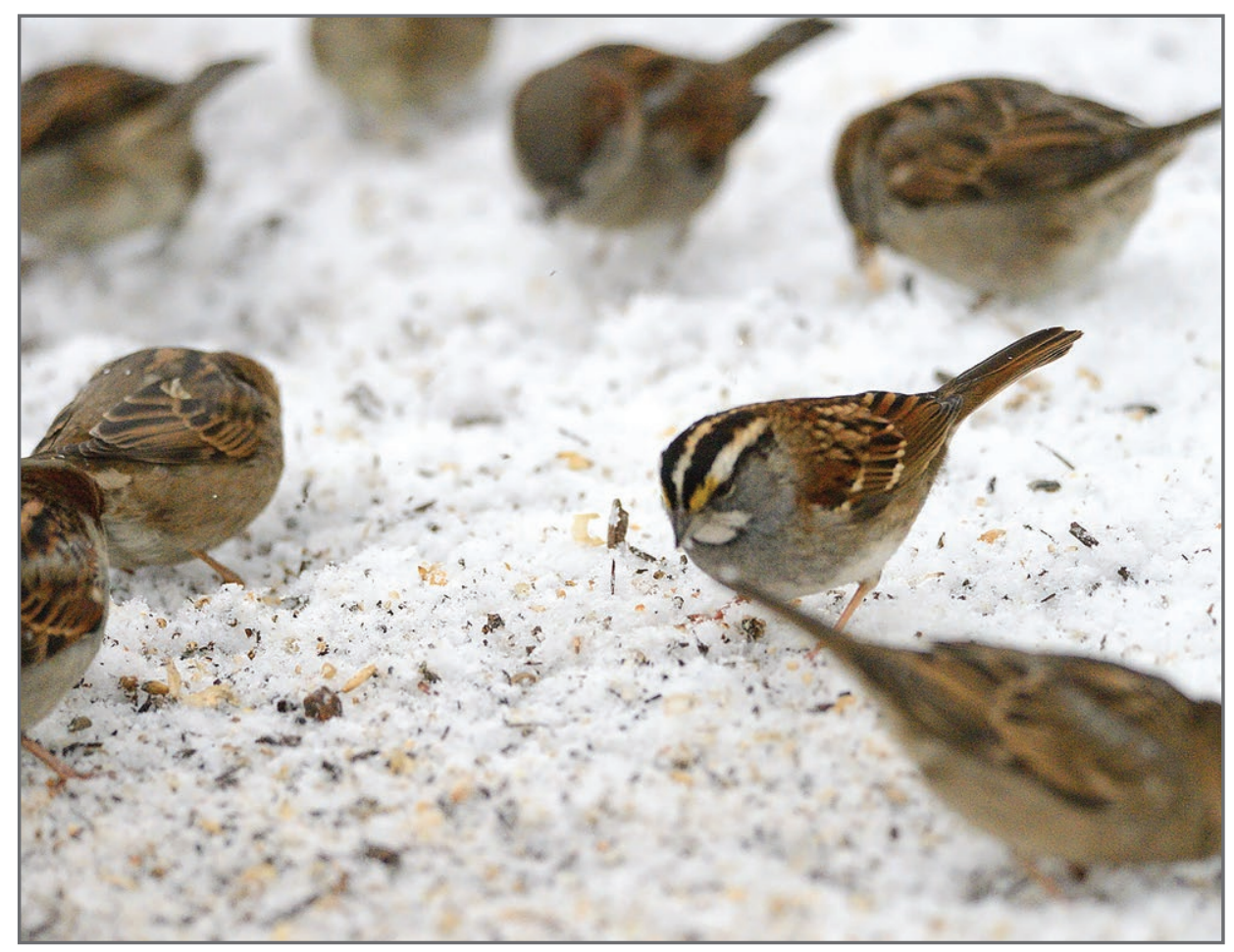

FIGURE 11. White-throated Sparrows are quite hardy and survive well if they can find an adequate food source. This bird was with House Sparrows at a downtown location on December 4, 2016. Photo credit: Garry Budyk.

3. Dunn EH, Francis CM, Blancher PJ, Drennan SR, Howe MA, Lepage D, Robbins CS, Rosenberg KV, Sauer JR, Smith KG. 2005. Enhancing the scientific value of the Christmas Bird Count. The Auk 122(1):338-46.

4. Jones RE. 2003. Gray Partridge in The Birds of Manitoba. Manitoba Naturalists Society, Winnipeg, Manitoba.

5. Transport Canada. 2015. Government of Canada Hopper Car Fleet: 2014 (Annual Report).

6. Holland GE, Taylor P. 2003. Mourning Dove in The Birds of Manitoba. Manitoba Naturalists Society, Winnipeg, Manitoba.

\section{Government of Canada. 2017}

Breeding Bird Survey results - Trend results for Mourning Dove. Retrieved from https://wildlife-species.canada. ca/breeding-bird-survey-results/P004/ $A 001 /$ lang $=e \& m=s \& r=M O D O \& p=L$.

8. U.S. Fish and Wildlife Service. 2007. Migratory bird hunting activity and harvest during the 2005 and 2006 hunting seasons: Preliminary estimates. U.S. Department of the Interior, Washington, D.C.

9. Swartz, J. 2018. Mourning Dove in Artuso, C., A. R. Couturier, K. D. De Smet, R. F. Koes, D. Lepage, J. McCracken, R. D. Mooi, and P. Taylor (eds.). The Atlas of the Breeding Birds of Manitoba, 2010-2014. Bird Studies Canada. Winnipeg, Manitoba.
19. Paul A. 2016. Home for a roost. Retrieved from https://www.winnipegfreepress.com/ local/Hundreds-of-ravens-turn-HealthSciences-Centre-into-a-scene-right-out-ofHitchcock-flick-367882071.html.

20. Taylor P, Mooi RD, Parsons RJ. 2016. History of the European Starling in Manitoba and nearby states and provinces. Blue Jay 74(3):32-43.

21. Royal Society for the Protection of Birds (U.K.). Undated. House Sparrow bird facts/ Passer domesticus. Retrieved from https:// www.rspb.org.uk/birds-and-wildlife/wildlifeguides/bird-a-z/house-sparrow.

22. Erskine AJ. 2006. Recent declines of House Sparrows, Passer domesticus, in Canada's Maritime Provinces. Canadian Field-Naturalist 120(1):43-49.

23. Royal Society for the Protection of Birds (U.K.). Undated. Causes of population decline of urban house sparrows. Retrieved from https://www.rspb.org.uk/our-work/ conservation/projects/causes-of-populationdecline-of-urban-house-sparrows/.

24. Cooper CB, Hochachka WM, Dhondt AA. 2007. Contrasting natural experiments confirm competition between House Finches and House Sparrows. Ecology 88(4):864-870.

11. Koes RF. 2010. Recent Bald Eagle breeding range expansion in Manitoba. Blue Jay 68(1):24-28.

\section{Fasoli A. 2014. American Kestrel} Partnership Kestrel Camera: A Struggle to Survive. Retrieved from www. nemesisbird. com/bird-science/american-kestrelpartnership-kestrel-camera-struggle-survive/.

13. American Kestrel Falco sparverius BBS trend map, 1966-2012. 2017. Retrieved from https://www.mbr-pwrc.usgs.gov/bbs/tr2012/ tr03600.htm.

14. De Smet KD. 2003. Merlin in The Birds of Manitoba. Manitoba Naturalists Society, Winnipeg, Manitoba.

15. Houston, CS. 1977. Changing patterns of Corvidae on the Prairies. Blue Jay 35(3): 149-156.

16. Government of Manitoba. 2002. West Nile Virus Bulletin \#8.

17. Taylor P. 2003. Common Raven in The Birds of Manitoba. Manitoba Naturalists Society, Winnipeg, Manitoba.

18. Greenslade B. 2016. Increasing number of ravens take to Winnipeg sky. Retrieved from https://globalnews.ca/news/2442315/ winnipeggers-counting-crows/ [sic].
25. Bonter DN, Harvey MG. 2008. Winter survey data reveal rangewide decline in Evening Grosbeak populations. Condor 110:376-381.

26. COSEWIC. 2016. COSEWIC assessment and status report on the Evening Grosbeak Coccothraustes vespertinus in Canada. Committee on the Status of Endangered Wildlife in Canada. Ottawa. xi + 64 pp. Retrieved from https://wildlife-species. canada.ca/species-risk-registry/document/ default_e.cfm?documentID=3190.

27. Bancroft J, Parsons RJ. 1991. Range expansion of the House Finch into the Prairie Provinces. Blue Jay 49(3):128-136.

28. Adelman JS, Moyers SC, Farine DR, Hawley DM. 2015. Feeder use predicts both acquisition and transmission of a contagious pathogen in a North American songbird. Proceedings of the Royal Society B 282: 20151429. Retrieved from https://royalsocietypublishing.org/doi/ full/10.1098/rspb.2015.1429.

29. eBird Northwest Team. 2014. Dark-eyed Junco races: Oregon, Slate-colored and Cassiar. Retrieved from https://ebird.org/ pnw/news/dark-eyed-junco-races-oregonslate-colored-and-cassiar/. 